\title{
Exploration Of Children's Music Talents As A Solution For The Development Of Millennial Generations In The Church Of Bethany Tanjung Anom Deli Serdang
}

\author{
Robert Simanjuntak \\ (robertselamat@yahoo.co.id) \\ Postgraduate Program, Pelita Kebenaran School of Theology
}

\begin{abstract}
Advancement in technologyhas a major impact on the development of the character of teenagersin the present era. Among many existing factors, the use of gadgets arguably has the biggest role in shaping the development youngsters nowadays. Excessive use of gadgetscan result in negative effects on an individual. For this problem, a solution is needed to constrain the use of gadgets by teenagers, including teenagers in churches. One solution is to direct the young people to develop musical talent from their teenage years. Playing musical instruments can help develop a person's character in a positive way provided that the church facilitates the development of musical talents of its teenage congregations. The research was conducted amongTanjungAnom Bethany Indonesia Church youths. Evidence showed that learning to play musical instruments for religious songs helps develop teenagers' character in a positive way and helps reduce the use of gadgets.

Keywords: Children, Talents Millenial Generations
\end{abstract}

\section{Introduction}

In this millennial era, we witness howmuch technology influences the lives of young people or teenagers. Technological advancement becomesa dominant factor in shaping the character of the millennial teenagers nowadays. Of course many factors contribute to the shapingof character of today's teenagers, such as education in the family, school education, spiritual education such as in the church and in other places of worship. However based on several studies, the most influencing factor in the shaping the character of millennial teenagers is the use of technology such as gadgets. There are several negative effectsas a result of excessive use of gadgets in children's development that make children causing them to be addicted. Among them is wasted time, brain impairment, the overwhelming number of features or applications that are unsuitable to children age group, disrupted health, and the diminishing interest in playing activities or social activities in the surrounding environment. All this may also psychologically impacts a person causing them lead to have low self esteem.

Many millennial teenagers actually have potential such as musical talent that can be developed as a way to anticipate the negative effects of digital technology use, while simultaneously building the character of teenagers so that they may have good personalities. Thus, this study attempts to investigate the extent to which the development of musical talent can bring a positive influence on mental development or character of millennial teenagers who are congregation members of Bethany Church, TanjungAnom, DeliSerdang. 


\section{Theoretical Review}

\subsection{Teenagers}

Which age group can be categorized as teenagers? According to the WHO, people who are at the transition stage between childhood and adulthood can be called teenagers. The WHO defines the age limit for teenagers, i.e., from 12 to 24 years. According to the Republic of Indonesia Ministry of Health in 2010, the age limit for teenagers is between 10 and 19 years old and not married. According to Papalia and Olds( 2011), teenage is a period of developmental transition between childhood and adulthood, generally starting at the age of 12 or 13 and ending in the late teens or early twenties. Thereforebased on the definition of teenagers from various sources above, it can be concluded that teenage is between the ages of 10 to 24 years, and thus what is called millennial teenagers are unmarried young people aged between 10 and 24 years, whose lives are frequently related to modern and digital technology.

\subsection{Music}

The word "music" comes from the Greek word mousikos, where the name is taken from one of the Greek gods. Mousikos is symbolized as a beauty God who has controls over the areas of science and art. In the KBBI (Indonesian Unabridged Dictionary), music is defined as an art or science that arranges sounds or notes in sequence, combination within a temporal relationship in produce continuous sound in unity. Various scientific studies have indicated that music can be used to help cure several diseases such as insomnia, stress, depression, pain, hypertension, obesity, parkinsonism, epilepsy, paralysis, arrhythmia, cancer, psychosomatic, reduce pain during childbirth, and other forms of pains. In general music serves several functions including:

1. Music as a means of self expression

2. Music as a means for entertainment

3. Music as a means of creativity

4. Music as a means of education

\subsection{Benefits of Learning Music}

Learning music or the developingand exploring music skills is a way to achieve the realization of one's self development. Developing musical skills can also enhance and foster the potential for the sense of beauty that a person has by experiencing and appreciatingmusic. Learning music is an avenue to develop creativity, especially in aesthetic creativity. Development of musical skills can also be an educational process that helps unveil one's ideas or notions that arise and environmental effects by using musical elements, thus producing a musical piece that can not be separated from the sense of beauty. According to Kusumawati( 2013 ), music art education has a very important role in forming a whole human character. Through directed learning and the development of musical skills, music can develop cultured humans who have a balance of their right and left brain (balance of mind, mind, and heart), and have mature personality.

Slameto( 2016 )posits that music players appreciate the beauty of playing music as the highest aesthetic value. Playing music is a means to channel the skills of teenagersit is in this situation that the church can provide the right motivation teenagers in the current era. The 
opportunity that is presented to the teenagers to develop musical skills can be an important moment to motivate teenagers. Therefore the hobby or preference of teenagers in this case playing music must be identified by parents or educators in order to take advantage of the situation as a doorway to motivate teenagers to reach their life goals and dreams.

\section{Research Methods}

This research applies descriptive qualitative approach. The technique of data collection is done by observation, library research, and interviews. Observations were made at the TanjungAnom Indonesian Bethany Church in Deli Serdang District, while interviews were conducted with teenagers who are the musicians the TanjungAnom Bethany Indonesia Church in Deli Serdang District with the purpose of obtaining information about their views on the development of musical skills. Interviews were conducted by using the in-depth interviewing method. Library research is carried out by investigating articles, journals and books. This study took samples of teenagers in Bethany TanjungAnom Church, Deli Serdang Regency from 10 to 24 years old.

\section{Results}

The respondents consisted of 4 teenagers aged 10-12 years, 3 teenagers aged 17-22 years, and 2 teenagers aged 23-24 years. Each respondent was given 6 questions about their musical experience and about the benefits they felt after playing music. The following are the results of interviews with respondents:

Question 1: How long have you been playing music?

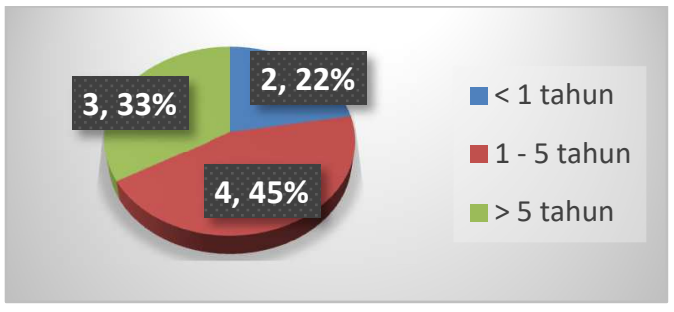

Question 2: How many instruments do you play?

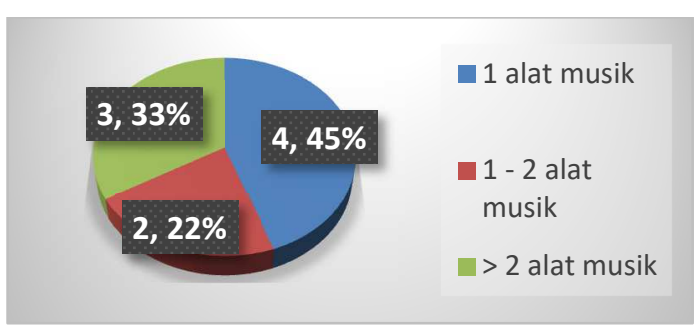


Question 3: Does playing music make you entertained?

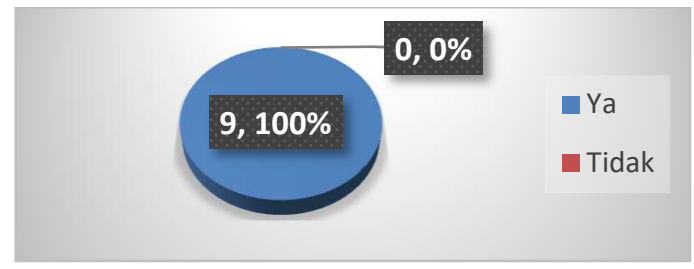

Question 4: Does playing music help you to love one another, particularly people whi are close to you?

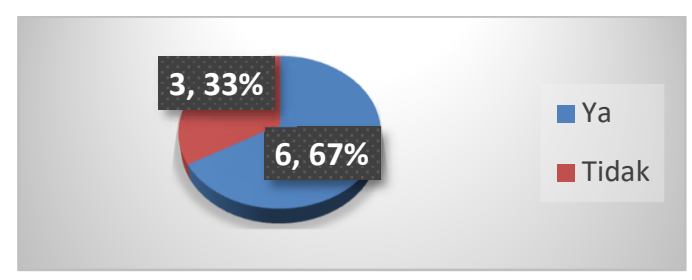

Question 5: Does playing music increase you love for The Lord and make you worship the Lord diligently?

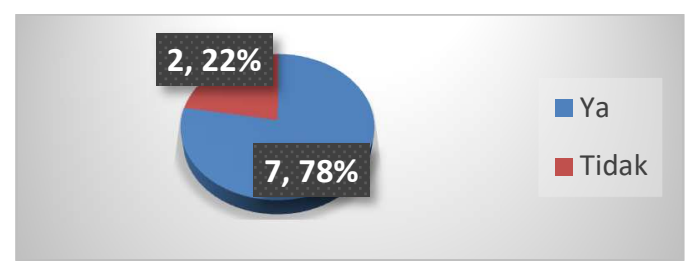

Question 6: Does playing music boost your self esteem?

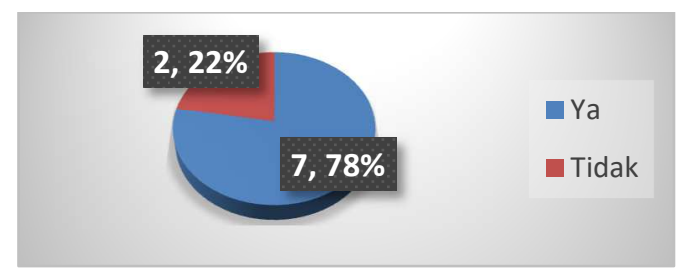

1. Teenagers in Bethany Indonesia Church TanjungAnom felt comforted while playing music.

2. Six 6 teenagers in the Indonesian Bethany Church in TanjungAnom become increasingly loving others especially those closest to them, while 3 teenagers do not feel that way.

3. A total of 7 teenagers in the Indonesian Bethany Church in TanjungAnom became increasingly loving God and diligently worshiping, while 2 teenagers did not feel that way.

4. A total of 7 teenagers in the Indonesian Bethany Church in TanjungAnom became more confident, while 2 teenagers did not feel that way.

5. Most of the teenagers of the TanjungAnom Bethany Indonesia Church experienced a change in character for the better after playing music.

\section{Conclusions}


Based on the analysis it can be concluded that the development of musical talents among teenagers is effective and perhaps necessary in order that the character of youngsters can be shaped into a Godly character,making them God's good children. It is recommended for churches to give serious attention to such matters because the teenage generation is the future of the church. By training teenagers to develop their musical talents, the church is actually also preserving its existence in the future.

Teaching teenagers to play musical instruments, particularly religious music has a positive effect. This is evident from the results of interviews that were conducted among teenagers who are members of Bethany Indonesia Church, TanjungAnom. Most of these teenagers experienced a transformation intobetter character after learning to playmusical instruments at church.

Suggestions for further research are: first of all,it is recommended that the respondents be multiplied in number and the scope of the interview be expanded. Second, the questions asked should be further extended.

\section{References}

[1] Ardipal. Model Pengembangan Karakter Melalui Pendidikan Seni di Sekolah Dasar. Fakultas Bahasa dan Seni. Universitas Negeri Padang. Sumatera Barat.

[2] Kartika, Dharsono Sony dan Nanang Ganda Perwira. 2004. Pengantar Estetika. Bandung: Rekayasa Sains.

[3] Pailang, Herianto Sande. Membangun Spiritual Remaja Masa Kini Berdasarkan Amsal 22:6. Page 21.

[4] Slameto. Pembinaan Karakter Guru Sekolah Kristen. Universitas Kristen Satya Wacana Salatiga. Page 5. 